\title{
ПОКАЗНИКИ СИСТЕМИ ЗСІДАННЯ ТА ТРОМБОЕЛАСТОГРАМИ У ХВОРИХ НА ГЕМОФІЛІЮ ПІД ЧАС ПРОФІЛАКТИЧНОГО ЛІКУВАННЯ НЕФАКТОРНИМ ПРЕПАРАТОМ siRNA-AT3
}

\author{
Красівська В., Стасишин О., Семерак М., \\ Тушницький О., Новак В.
}

ДУ «Інститут патологї̈ крові та трансфузійної медицини НАМН Украӥни», Львів, Україна

\section{Резюме}

Мета. Вивчити роль тромбоеластографії (ТЕГ) у контролі терапії та оцінити вплив підшкірного препарату siRNA-AT3 на систему гемостазу на основі аналізу коагулологічних показників та параметрів тромбоеластограми під час профілактичного лікування хворих на гемофілію.

Матеріали і методи. Об'єктом дослідження були коагулологічні показники та параметри тромбоеластограми 12 хворих на гемофілію $A$ i $B$ з інгібіторами та без інгібіторів, які протягом 9 міс отримували профілактичне лікування nідикірним препаратом siRNA-AT3 у дозі 0,8 мл 1 раз на місящь. Усім хворим до та під час профілактичного лікування проводили скринінгові коагулологічні дослідження, визначали активність фактора зсідання VIII (IX), титр інгібітору до фактора VIII (IX), активність антитромбіну III (АTIII) та виконували ТЕГ.

Результати. I групу становили 12 хворих на гемофілію до лікування, до II групи увійшли ті самі пацієнти під час профілактичного введення siRNA-AT3. У обох групах хворих коагулологічні показники, які характеризують коагуляиійний гемостаз та активність факторів зсідання, були значно порушеними, щзо пов'язане з дефіцитом прокоагулянту. Під час лікування достовірної різниці між групами не виявлено, щуо вказує на відсутність впливу препарату на коагуляційний гемостаз. За результатами TEГ під час терапї̈ siRNA-AT3 відбувалась нормалізація параметрів, які характеризують властивості згустку (стабільність та міцність $G$, ступінь фібринолізу через 30 хв. після утворення згустку LY30 та тромбодинамічний потенціальний індекс TPI/c), не відрізнялись від контрольної групи. Отримані у ТЕГ дані вказують на утворення стабільного, міцного, якісного та ефективного згустку з достатніми гемостатичними можливостями.

Висновки. Встановлено, щзо механізм дї та впливу на гемостаз препарату siRNAAT3, відображений у TEГ. Ефект впливу siRNA-AT3 можна спостерігати на кінцевому етапі процесу зсідання крові - утворенні тромбіну (тромбопластину) та формуванні згустку. Лікування нефакторним препаратом siRNA-AT3 не потребує контролю за допомогою коагулологічних тестів дослідження 
гемостазу. ТЕГ може бути достатньо надійним глобальним тестом для контролю терапї нефакторним препаратом siRNA-AT3.

Ключові слова: гемофілія, нефакторні препарати, тромбоеластографія.

Конфлікт інтересів: автори заявляють про відсутність конфліктів інтересів.

Фінансування: дослідження не мало спонсорської підтримки.

\title{
TESTS OF BLOOD CLOTTING SYSTEM AND THROMBOELASTOGRAM IN PATIENTS WITH HEMOPHILIA DURING THE NON-FACTORY PRODUCT siRNA-AT3 PROPHYLACTIC TREATMENT
}

\author{
Krasivska V., Stasyshyn O., Semerak M., Tushnytskyi O., Novak V. \\ SI «Institute of Blood Pathology and Transfusion Medicine of NAMS of Ukraine», \\ Lviv, Ukraine
}

\begin{abstract}
Aim. To study the role of thromboelastography (TEG) in the control of therapy and to evaluate the effect of subcutaneous drug siRNA-AT3 on the hemostasis system based on the analysis of coagulological tests and thromboelastogram parameters during prophylactic treatment of patients with hemophilia.

Materials and methods. The objects of the study were coagulological tests and parameters of thromboelastogram of 12 patients with hemophilia $A$ and $B$ with and without inhibitors, who for 9 months received prophylactic treatment with subcutaneous product siRNA-AT3 at a dose of $0,8 \mathrm{ml} 1$ time per month. All patients before and during prophylactic treatment were performed for coagulation tests, coagulation factor VIII (IX) activity, factor VIII (IX) inhibitor titer, antithrombin III (ATIII) activity, and TEG were provided.

Results. The first group consisted of 12 patients with hemophilia before treatment, the second group included the same patients during the prophylactic administration of siRNA-AT3. In both groups of patients, coagulation parameters, which characterize coagulation hemostasis and coagulation factor activity, were significantly impaired due to procoagulant deficiency. During treatment, no significant difference between the groups was found, which indicates the lack of effect of the drug on coagulation hemostasis. According to the results of TEG during siRNA-AT3 therapy, the parameters characterizing the properties of the clot (stability and strength $G$, the degree of fibrinolysis $30 \mathrm{~min}$ after clot formation LY30 and thrombodynamic potential index TPI/s) were normalized and did not differ from the control group. The data obtained in TEG indicate the formation of a stable, strong, high-quality, and effective clot with sufficient hemostatic capabilities.
\end{abstract}

Conclusions. It was found that the mechanism of action and effect on the hemostasis of the drug siRNA-AT3, reflected in the thromboelastogram. The effect of siRNA-AT3 can 
be observed at the final stage of the blood clotting process - the formation of thrombin (thromboplastin) and clot formation. Treatment with the non-factorial drug siRNA-AT3 does not require monitoring by coagulation tests for hemostasis. TEG may be a sufficiently reliable global test to monitor treatment with the non-factor drug siRNA-AT3.

Keywords: hemophilia, non-factor products, thromboelastography.

\section{Вступ}

Для лікування гемофілії доступні різні типи гемостатичних засобів, до яких відносять концентрати факторів коагуляції та нефакторні препарати, такі як еміцизумаб, концізумаб та siRNA-AT3 [1]. 3 появою цих нових альтернативних препаратів, механізм дії яких спрямований на мімікрію факторів зсідання крові та/або зміну балансу у системі зсідання крові, актуальним постає питання лабораторного контролю за терапією цими препаратами [1-3]. Також продовжуються дослідження механізму дії цих препаратів на систему зсідання у хворих на гемофілію та ефективності різних коагулологічних тестів для моніторингу. Відомо, що при введенні цих препаратів вміст ФVIII (IX) не зростає, тому традиційні тести, такі як активований частковий тромбопластиновий час (АЧТЧ) та активність факторів зсідання, не придатні для контролю лікування [1-3]. Для оцінки дії концізумабу деякі дослідники рекомендують досліджувати зовнішній шлях зсідання із застосуванням тесту розведеного протромбінового часу (ПЧ), який активізується після активації зсідання з тканинним фактором. При визначенні розведеного ПЧ спостерігається зменшення часу згортання, залежно від дози концізумабу [5, 6]. При застосуванні siRNAAT3, який впливає на зсідання крові на всіх етапах формування згустку, актуальним є визначення активності антитромбіну III (ATIII), продуктів деградації фібриногену в паракоагуляційних тестах [7].

На думку численних авторів для оцінки гемостазу під час лікування нефакторними препаратами перспективним $\epsilon$ застосування глобальних тестів, до яких відносять тромбоеластографію (ТЕГ) та тест генерації тромбіну (ТГТ) [8-11]. Ці лабораторні аналізи засновані на комплексній оцінці коагуляції [12-14]. На відміну від традиційних методів, віскозиметричний метод ТЕГ висвітлює динаміку коагуляції у часі, іiї параметри забезпечують більш детальну інформацію про процес зсідання і можуть відображати як гіпо-, так і гіперкоагуляцію. ТЕГ забезпечує глобальну оцінку системи зсідання від ініціації утворення і розвитку згустку до фібринолізу в природних умовах, що включає взаємодію клітинних і плазматичних компонентів [8-14]. Результат записується у вигляді тромбоеластограми. Вважають, що глобальні методи оцінки гемостазу 
більш точно, на клітинному рівні відображають фізіологічні процеси та механізми впливу терапевтичних препаратів Звичайні коагулологічні показники, такі як АЧТЧ або ПЧ, відображають лише перші ознаки генерації фібрину, коли тільки $\sim 5 \%$ тромбіну утворюється у кінцевій точці коагуляції [8-13]. 3 іншого боку, ТЕГ не є заміною для звичайних коагуляційних тестів, а лише доповнює їхні результати. Тому дані ТЕГ слід інтерпретувати з обережністю, беручи до уваги клінічні прояви i результати інших лабораторних досліджень.

Отже, немає ніяких стандартних процедур вибору найбільш ефективного агента і моніторингу гемостатичних ефектів або, в окремих випадках, тромботичних ризиків. Тому пошук комплексу інформативних лабораторних методів оцінки гемостатичної дії та контролю лікування хворих на гемофілію нефакторними препаратами залишається актуальним завданням.

Мета. Вивчити роль ТЕГ у контролі терапії та оцінити вплив підшкірного препарату siRNA-AT3 на систему гемостазу на основі аналізу коагулологічних показників та параметрів тромбоеластограми під час профілактичного лікування хворих на гемофілію.

\section{Матеріали і методи}

Протягом 9 місяців під спостереженням знаходились 12 хворих на гемофілію, віком від 19 до 35 років, які отримували профілактичне лікування підшкірним препаратом siRNA-AT3 у дозі 0,8 мл 1 раз на місяць. Серед них 8 хворих на тяжку форму гемофілії А (1 - 3 інгібіторами до ФVIII) та 4 хворих на тяжку форму гемофілії В без інгібіторів. Дослідження показників коагулологічних тестів та ТЕГ виконано декілька разів протягом 9 міс. та загальна кількість спостережень становила 24. Усі учасники підписали згоду на участь у дослідженні, були ознайомлені 3 метою, основними положеннями, дизайном та процедурами дослідження, характеристиками досліджуваного препарату, користю та ризиками дослідження, своїми правами та нормативними вимогами. Під час дослідження дотримувалась конфіденційність щодо даних пацієнтів. Протокол дослідження був схвалений Локальним Комітетом з медичної етики.

Контрольну групу для визначення нормальних коагулологічних показників склали 20 здорових осіб (10 чоловіків і 10 жінок середнього віку), які не приймали жодних ліків. Нормальні контрольні діапазони значень (референтний інтервал) показників ТЕГ для цитратних нативних зразків крові взято з літературних даних та надані виробником $[14,15]$.

Для загальної оцінки стану системи гемостазу виконували скринінгові дослідження, які включали: протромбіновий час за Quick; (ПЧ); активо- 
ваний частковий тромбопластиновий час (АЧТЧ); визначення концентрації фібриногену за Клаусом. Рівень дефіцитного фактора зсідання VIII (IX) ФVIII(IX) визначали за уніфікованою одностадійною методикою [16]. Кількісне визначення інгібіторів до ФVIII(IX) проводили Nijmegen Bethesda - методом, результати подано у Бетезда одиницях на мл (БО/мл) $[16,17]$ та позитивним вважали результат при титрі $\geq 0,6$ БО/мл.

Кількісне визначення активності АТІІІ проводили хромогенним антитромбін (Ха) методом [18]. Усі коагулологічні дослідження та визначення ATIII виконували на напівавтоматичному коагулометрі Helena-C4 № C4-2561 (Helena Bioscience Europe, Великобританія).

Для проведення ТЕГ використовували кров, яка була стабілізована 3,2 \% розчином цитрату натрію у співвідношенні: 1 частина стабілізатора до 9 частин крові. У кювету тромбоеластографа додавали 340 мкл цитратної крові та 20 мкл 0,2 $\mathrm{M}$ розчину $\mathrm{CaCl}_{2}$. ТЕГ виконували на тромбоеластографі TEG 5000 ${ }^{\circledR}$ Haemoscope Corp., Niles IL, №S091204020. Було проаналізовано такі показники системи зсідання як: час реакції ( $\mathrm{R}$, хвилини); час коагуляції або формування згустку (К, хв); кут дотичної до тромбоеластограми з точки початку утворення згустку ( $\alpha$-Angle, градуси); максимальну амплітуду (МА, мм); коагуляційний індекс - потенціал крові пацієнта в цілому (CI); час з моменту внесення плазми до кювети тромбоеласторгафа до утворення першої формації фібрину - початкове утворення фібрину (SP, хв); стабільність та міцність згустку (G, діни/см²); LY30характеристика процесу розчинення згустку за 30 хв після досягнення MA або ступінь фібринолізу через 30 хв після утворення згустку; тромбодинамічний потенціальний індекс (TPI/c) [8, 12-15]. Значення R та K зафіксовані протягом 10 хв. після ініціації процесу зсідання у кювети тромбоеластографа, $\alpha$-Angle, MA, G та LY30 - протягом 30 хвилин.

Статистичну обробку матеріалу виконали за допомогою пакетів прикладних програм STATISTICA for Windows 6,0 (Statsoft, USA). Порівняння параметричних показників між групами здійснювали за допомогою критерію Манн-Уітні та подавали їх як медіану, мінімум, максимум, нижній-верхній квартилі. Вірогідність отриманих результатів оцінювали на рівні достовірності не менше $95 \%(\mathrm{p}<0,05)$.

\section{Результати та їх обговорення}

Усіх хворих було поділено на 2 групи. До I групи ми віднесли 12 хворих на гемофілію до лікування, до II групи увійшли ті самі пацієнти під час профілактичного введення siRNA-AT3. Титр інгібіторних антитіл до ФVIII у хворого на гемофілію А становив 25,6 БО/мл (норма 
$<0,6$ БО/мл). Результати коагулологічних досліджень та показники ТЕГ подано у таблиці. У обох групах показник ПЧ був достовірно подовженим порівняно із контролем, медіана становила $12,5(10,5-15,2)[11,4-12,8]$ с для I групи та $12,1 \quad(11,4-13,6)$ [11,8-13,0] с для II групи відповідно $\left(\mathrm{p}_{\mathrm{I}-\mathrm{H}}=0,009\right.$ та $\left.\mathrm{p}_{\mathrm{II-н}}=0,000\right)$. Між групами достовірної різниці не встановлено. Значення міжнародного нормалізованого співвідношення (МНC) до лікування та під час лікування препаратом $s i$ RNA-AT3 не відрізнялось від нормальних значень (у всіх випадках $\mathrm{p}>0,05$ ). У хворих на гемофілію I та II групи показник АЧТЧ був значно подовженим, порівняно із контролем

Таблиця. Показники системи зсідання та ТЕГ 12 хворих на гемофілію (24 випадки) під час профілактичного лікування альтернативним підшкірним препаратом siRNA-AT3

\begin{tabular}{|c|c|c|}
\hline $\begin{array}{c}\text { Показник } \\
\text { (норма) }\end{array}$ & I група, $n=12$ & II група, $n=12$ \\
\hline \multicolumn{3}{|c|}{ Коагулологічні показники } \\
\hline ПЧ, с $(9,4-12,5)$ & $12,5(10,5-15,2)[11,4-12,8]^{*}$ & $12,1(11,4-13,6)[11,8-13,0]^{*}$ \\
\hline MHC $(0,9-1,1)$ & $1,0(0,9-1,3)[1,0-1,1]$ & $1,1(1,0-1,1)[1,0-1,1]$ \\
\hline АЧТЧ, с $(25,1-36,5)$ & $81,4(67,4-100,0)[71,2-96,8]^{*}$ & $82,7(48,7-108,0)[68,1-92,8]^{*}$ \\
\hline Фібриноген г/л $(2,0-4,0)$ & $2,7(1,67-3,1)[2,18-3,0]$ & $2,4(1,7-3,1)[1,9-3,0]^{*}$ \\
\hline $\begin{array}{l}\text { Активність ФVIII (IX), \% } \\
(60,0-200,0)\end{array}$ & $0,5(0,30-0,70)[0,4-0,7]^{*}$ & $0,5(0,30-1,1)[0,4-0,8]^{*}$ \\
\hline ATIII, \% $(75,0-135,0)$ & $115,9(95,0-120,4)[104,7-118,0]^{\#}$ & $14,3(7,8-19,8)[12,6-15,6]^{*}$ \\
\hline \multicolumn{3}{|c|}{ Показники ТЕГ } \\
\hline $\mathrm{R}, \mathrm{xв}(4,0-11,0)$ & $57,1(47,2-89,4)[53,2-69,0]^{* \#}$ & $24,0(9,1-52,2)[18,8-41,4]^{*}$ \\
\hline К, хв. $(1,0-4,0)$ & - & $5,9(0,0-12,5)[3,8-7,2]^{*}$ \\
\hline MA, мм $(54,0-72,0)$ & - & $45,9(7,9-63,7)[40,1-51,6]^{*}$ \\
\hline$\alpha$-Angel, град $(47,0-74,0)$ & - & $33,1(12,0-66,9)[28,3-43,0]^{*}$ \\
\hline CI $(-3,0-+3,0)$ & - & $-3,8(-11,0-1,0)[-8,5-(-1,7)]^{*}$ \\
\hline SP, хв. $(0,25-15,0)$ & $56,1(46,0-89,4)[52,4-74,4]^{* \#}$ & $21,5(0,2-47,6)[18,2-36,8]^{*}$ \\
\hline $\mathrm{G}$, діни $/ \mathrm{cm}^{2}(6,0-13,2)$ & - & $4,2(0,4-8,8)[3,3-5,3]$ \\
\hline LY30, \% $(0,0-8,0)$ & - & $2,5(0,0-28,7)[1,4-10,8]$ \\
\hline TPI /c $(3,0-20,0)$ & - & $6,6(0,0-17,4)[4,0-9,6]$ \\
\hline
\end{tabular}

Примітки: 1. Показники подано як «медіана (мінімум-максимум) [нижній верхній квартилі]», 2. ${ }^{*}$ - Різниця 3 показником контрольної групи значуща (p н $<0,05), 3 .{ }^{\#}$ - Різниця показників між I і II групою значуща (p I-II $\left.<0,05\right)$, 4. - неможливо визначити у зв'язку із гіпокоагуляцією, siRNA-AT3 - досліджуваний препарат.

Пояснення скорочень показників ТЕГ подано у матеріалах і методах. 
(у всіх випадках $\mathrm{p}<0,05)$, що свідчить про суттєву гіпокоагуляцію, яка притаманна хворим на гемофілію і $\epsilon$ пов'язаною із дефіцитом прокоагулянту. Під час лікування АЧТЧ не змінювався і становив 81,4(67,4100,0)[71,2-96,8] с та 82,7(48,7-108,0)[68,1-92,8] с відповідно, що вказує на відсутність впливу препарату на коагуляційний гемостаз. У хворих II групи фібриноген був достовірно нижчим 2,4(1,7-3,1)[1,9-3,0] г/л, порівняно iз контрольною групою; $\mathrm{p}_{\mathrm{II}-\mathrm{H}}=0,0254$. Між групами значення фібриногену не відрізнялись (див. таблицю). У хворих обох груп активність ФVIII (IX) була значно зниженою, порівняно із контролем (у всіх випадках $\mathrm{p}<0,05)$, та під час лікування рівень фактора не зростав i становив $0,5(0,3-0,7)[0,4-0,7] \%$ та $0,5(0,3-1,1)[0,4-0,8] \%$ відповідно, що вказує на відсутність впливу препарату на коагуляційний гемостаз. Між групами значення вмісту фактора не відрізнялись.

До лікування значення АТIII знаходились в межах норми 115,9(95,0120,4)[104,7-118,0] \%, та під час профілактики siRNA-AT3 був достовірно нижчим (медіана 14,3(7,8-19,8)[12,6-15,6]\%), ніж у I групі та у здорових осіб; $\mathrm{p}_{\text {I-II }}=0,0000$. Відомо, що siRNA-AT3 працює за допомогою нового та інноваційного механізму та діє на іншу мішень, ніж попередні препарати проти гемофілії. Активний інгредієнт знижує концентрацію антитромбіну i, таким чином, забезпечує достатнє утворення тромбіну. Відновлений таким чином гемостаз запобігає кровотечам, які є головним симптомом при цьому геморагічному захворюванні. siRNA-AT3 використовує принцип РНК - інтерференції (RNAi) - процесу затихання генів у клітинах. Так звані малі інтерферуючі РНК (siРHК), тобто малі молекули РНК, викликають селективний розпад комплементарної мРНК. Тому для трансляції білка відсутня мРНК. В результаті концентрація білка, який він кодує, також падає. За допомогою препарату siRNA-AT3 в організм потрапляє siРНК, яка діє проти мРНК, що кодує антитромбін. Таким чином це перешкоджає синтезу антикоагулянту та його вміст у плазмі знижується [19, 20].

До лікування параметри тромбоеластограми, які характеризують коагуляційний, гемостаз були значно подовженими, що зумовлено дефіцитом ФVIII(IX) у хворих на гемофілію (див. таблицю). У II групі під час профілактичного лікування препаратом siRNA-AT3 значення час реакції $\mathrm{R}$ значно вкорочувався до 24,0(9,1-52,2)[18,8-41,4] хв., порівняно iз I групою (медіана 57,1(47,2-89,4)[53,2-69,0] хв.), але все ще залишався достовірно порушеним ( $\left.\mathrm{p}_{\mathrm{II}-н}=0,000\right)$ відносно здорових осіб (рисунок). Час коагуляції або формування згустку $K$, кут дотичної $\alpha$-Angle, максимальна амплітуда МА, коагуляційний потенціал крові пацієнта СI, 
час початкового утворення фібрину SP у II групі залишались порушеними у бік гіпокоагуляції, на що вказує значуща різниця із відповідними параметрами контрольної групи (у всіх випадках $\mathrm{p}<0,05$ ). Під час лікування стабільність та міцність згустку $\mathrm{G}$, ступінь фібринолізу через 30 хв після утворення згустку LY30 та тромбодинамічний потенціальний індекс ТРІ/с нормалізувались до 4,2(0,4-8,8)[3,3-5,3] діни/см², 2,5(0,0 $28,7)[1,4-10,8] \%$ та $6,6(0,0-17,4)[4,0-9,6]$ відповідно; у всіх випадках $\mathrm{p}_{\text {II-н }}>0,05$. Порівняти більшість показників ТЕГ між I і II групами неможливо, оскільки їх вимірювання утруднене в зв'язку із значними порушеннями гемостазу у хворих на гемофілію I групи. За результатами дослідження нормалізація параметрів тромбоеластограми, які характеризують властивості згустку, що вказує на утворення стабільного, міцного, якісного та ефективного згустку з достатніми гемостатичними можливостями у хворого на гемофілію під час профілактичного лікування препаратом siRNA-AT3.

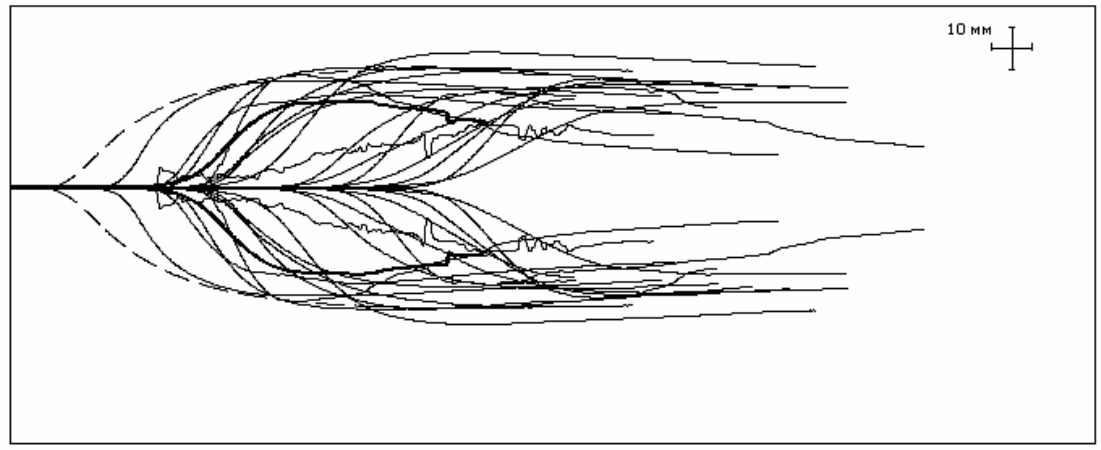

Рисунок. ТЕГ 12 хворих на гемофілію під час профілактичного лікування підшкірним препаратом siRNA-AT3 у дозі 0,8 мл шэомісяия

\section{Висновки}

1. Отримані результати свідчать, що механізм дії та вплив на гемостаз препарату siRNA-AT3, застосованого для профілактичного лікування хворих на гемофілію, відображений у тромбоеластограмі. Ефект препарату забезпечується потраплянням у організм siPНК, яка шляхом інтерференції спричиняє селективний розпад комплементарної мРНК, що кодує синтез антитромбіну, з подальшим зниженням його вмісту.

2. Вплив siRNA-AT3 можна спостерігати на кінцевому етапі процесу зсідання крові - утворенні тромбіну (тромбопластину) та формуванні згустку. Під час лікування відбувається нормалізація параметру G, що 
характеризує стабільність та міцність згустку, ступеню фібринолізу LY30 і тромбодинамічного потенціального індексу ТPI/c. Відмічається утворення стабільного, міцного, якісного та ефективного згустку з достатніми гемостатичними можливостями.

3. Лікування siRNA-AT3 не потребує контролю за допомогою коагулологічних тестів дослідження гемостазу.

4. ТЕГ може бути достатньо надійним глобальним тестом для контролю терапії нефакторним препаратом siRNA-AT3.

\section{Література}

1. Srivastava A., Santagostino E., Dougall A., Kitchen S., Megan S., Pipe S. W., et al. WFH Guidelines for the Management of Hemophilia. 3rd edition. Haemophilia. 2020 Aug 03. 26 (s6): 1-158.

DOI: $10.1111 /$ hae.14046.

2. Blair H. A. Emicizumab: a review in haemophilia A. Drugs. 2019 Oct. 79 (15): 1697 - 707.

DOI: 10.1007/s40265-019-01200-2.

3. Pruthi R.K. Laboratory monitoring of new hemostatic agents for hemophilia. Semin Hematol. 2016 Jan. 53 (1): 28-34. DOI: 10.1053/j.seminhematol. 2015.10.003.

4. Machin N., Ragni M.V. An investigational RNAi therapeutic targeting antithrombin for the treatment of hemophilia A and B. J Blood Med. 2018 Aug 22. 9: 135-40.

DOI: $10.2147 /$ JBM.S159297

5. Waters E.K., Sigh J., Friedrich U., Sørensen B. B. et al. Concizumab, an anti-tissue factor pathway inhibitor antibody, induces increased thrombin generation in plasma from haemophilia patients and healthy subjects measured by the thrombin generation assay. Haemophilia. 2017 Sep. 23(5): 769-76. DOI: $10.1111 /$ hae. 13260 .

\section{References}

1. Srivastava A., Santagostino E., Dougall A., Kitchen S., Megan S., Pipe S. W., et al. WFH Guidelines for the Management of Hemophilia. 3rd edition. Haemophilia. 2020 Aug 03. 26 (s6): 1-158.

DOI: $10.1111 /$ hae.14046.

2. Blair H. A. Emicizumab: a review in haemophilia A. Drugs. 2019 Oct. 79 (15): 1697 - 707.

DOI: 10.1007/s40265-019-01200-2.

3. Pruthi R.K. Laboratory monitoring of new hemostatic agents for hemophilia. Semin Hematol. 2016 Jan. 53 (1): 28-34. DOI: $10.1053 /$ j.seminhematol. 2015.10.003.

4. Machin N., Ragni M.V. An investigational RNAi therapeutic targeting antithrombin for the treatment of hemophilia A and B. J Blood Med. 2018 Aug 22. 9: 135-40.

DOI: $10.2147 /$ JBM.S159297

5. Waters E.K., Sigh J., Friedrich U., Sørensen B. B. et al. Concizumab, an anti-tissue factor pathway inhibitor antibody, induces increased thrombin generation in plasma from haemophilia patients and healthy subjects measured by the thrombin generation assay. Haemophilia. 2017 Sep. 23(5): 769-76. DOI: 10.1111/hae.13260. 
6. Chowdary P., Lethagen S., Friedrich U., Brand B., Hay C., Abdul Karim F. et al. Safety and pharmacokinetics of anti-TFPI antibody (concizumab) in healthy volunteers and patients with hemophilia: a randomized first human dose trial. Journal of Thrombosis and Haemostasis. 2015 May. 13 (5): 743-54. DOI: 10.1111/jth.12864

6. Negrier C., Ragni M.V., Georgiev P., Lissitchkov T. J., Van Nguyen H., Madigan K., et al. Perioperative management in patients with hemophilia receiving fitusiran, an investigational RNAi therapeutic targeting antithrombin for the treatment of hemophilia. Blood. 2017. 130 (1): 2366.

DOI: 10.1182/blood.V130.Suppl_1. 2366.2366

8. Lancé Marcus D. A general review of major global coagulation assays: thrombelastography, thrombin generation test and clot waveform analysis. Thrombosis J. 2015 Jan 12.13: 1-6. DOI: 10.1186/1477-9560-13-1

9. Young G., Sørensen B., Dargaud Y., Negrier C., Brummel-Ziedins K., Key N. S. Thrombin generation and whole blood viscoelastic assays in the management of hemophilia: current state of art and future perspectives. Blood. 2013 Mar 14. 121 (11): 1944-50. DOI:10.1182/blood-201208-378935

10. Chitlur M., Rivard G. E., Lillicrap D., Mann K., Shima M., Young G., Factor VIII, Factor IX, and Rare Coagulation Disorders Subcommittee of the Scientific and Standardisation Committee of the International Society on Thrombosis and Haemostasis. Recommendations for performing thromboelastography/thromboelastometry in hemophilia: commu-
6. Chowdary P., Lethagen S., Friedrich U., Brand B., Hay C., Abdul Karim F. et al. Safety and pharmacokinetics of anti-TFPI antibody (concizumab) in healthy volunteers and patients with hemophilia: a randomized first human dose trial. Journal of Thrombosis and Haemostasis. 2015 May. 13 (5): 743-54. DOI: 10.1111/jth.12864

7. Negrier C., Ragni M.V., Georgiev P., Lissitchkov T. J., Van Nguyen H., Madigan K., et al. Perioperative management in patients with hemophilia receiving fitusiran, an investigational RNAi therapeutic targeting antithrombin for the treatment of hemophilia. Blood. 2017. 130 (1): 2366. DOI: 10.1182/blood.V130.Suppl_1. 2366.2366

8. Lancé Marcus D. A general review of major global coagulation assays: thrombelastography, thrombin generation test and clot waveform analysis. Thrombosis J. 2015 Jan 12.13: 1-6. DOI: 10.1186/1477-9560-13-1

9. Young G., Sørensen B., Dargaud Y., Negrier C., Brummel-Ziedins K., Key N. S. Thrombin generation and whole blood viscoelastic assays in the management of hemophilia: current state of art and future perspectives. Blood. 2013 Mar 14. 121 (11): 1944-50. DOI:10.1182/blood-201208-378935

10. Chitlur M., Rivard G. E., Lillicrap D., Mann K., Shima M., Young G., Factor VIII, Factor IX, and Rare Coagulation Disorders Subcommittee of the Scientific and Standardisation Committee of the International Society on Thrombosis and Haemostasis. Recommendations for performing thromboelastography/thromboelastometry in hemophilia: commu- 
nication from the SSC of the ISTH. Journal of Thrombosis and Haemostasis. 2014 Jan. 12: 103-6.

DOI: $10.1111 /$ jth. 12458

12. Furukawa S., Nogami K., Ogiwara K., Yada K., Minami H., Shima M. Systematic monitoring of hemostatic management in hemophilia A patients with inhibitor in the perioperative period using rotational thromboelastometry. Journal of Thrombosis and Haemostasis. 2015 Jul. 13(7): 1279-84. DOI: $10.1111 /$ jth. 12987

13. Da Luz L. T., Nascimento B., Shankarakutty A. K., Rizoli S., Adhikari N. K. Effect of thromboelastography $(T E G \AA)$ and rotational thromboelastometry $($ ROTEM $\AA)$ on diagnosis of coagulopathy, transfusion guidance and mortality in trauma: descriptive systematic review. Critical Care. 2014 Sep 27. 18 (5): 518.

DOI: 10.1186/s13054-014-0518-9

13. Verma A., Hemlata. Thromboelastography as a novel viscoelastic method for hemostasis monitoring: Its methodology, applications, and constraints. Global Journal of Transfusion Medicine. 2017 Jan. 2(1): 8-18. DOI:10.4103/GJTM.GJTM_4_17

14. Roeloffzen W.W., Kluin-Nelemans H.C., Mulder A.B., Veeger N.J., Bosman L., de Wolf J.T. In Normal Controls, Both Age and Gender Affect Coagulability as Measured by Thrombelastography. Anesthesia \& Analgesia. 2010 Apr 01. 110 (4): 987-94.

DOI: $10.1213 / a n e .0 b 013 \mathrm{e} 3181 \mathrm{~d} 31 \mathrm{e} 91$

15. Scarpelini S., Rhind S.G., Nascimento B., Tien H., Shek P.N., Peng H.T. et.al. Normal range values for thromboelastography in healthy adult volunteers. Braz. J. Med. Biol. nication from the SSC of the ISTH. Journal of Thrombosis and Haemostasis. 2014 Jan. 12: 103-6.

DOI: $10.1111 /$ jth. 12458

11. Furukawa S., Nogami K., Ogiwara K., Yada K., Minami H., Shima M. Systematic monitoring of hemostatic management in hemophilia A patients with inhibitor in the perioperative period using rotational thromboelastometry. Journal of Thrombosis and Haemostasis. 2015 Jul. 13(7): 1279-84. DOI: $10.1111 /$ jth. 12987

14. Da Luz L. T., Nascimento B., Shankarakutty A. K., Rizoli S., Adhikari N. K. Effect of thromboelastography $\left(T^{\circledR}{ }^{\circledR}\right)$ and rotational thromboelastometry $\left(\right.$ ROTEM $\left.{ }^{\circledR}\right)$ on diagnosis of coagulopathy, transfusion guidance and mortality in trauma: descriptive systematic review. Critical Care. 2014 Sep 27. 18 (5): 518.

DOI: $10.1186 / \mathrm{s} 13054-014-0518-9$

13. Verma A., Hemlata. Thromboelastography as a novel viscoelastic method for hemostasis monitoring: Its methodology, applications, and constraints. Global Journal of Transfusion Medicine. 2017 Jan. 2(1): 8-18. DOI: 10.4103/GJTM.GJTM_4_17

14. Roeloffzen W.W., Kluin-Nelemans H.C., Mulder A.B., Veeger N.J., Bosman L., de Wolf J.T. In Normal Controls, Both Age and Gender Affect Coagulability as Measured by Thrombelastography. Anesthesia \& Analgesia. 2010 Apr 01. 110 (4): 987-94.

DOI: 10.1213/ane.0b013e3181d31e91

15. Scarpelini S., Rhind S.G., Nascimento B., Tien H., Shek P.N., Peng H.T. et.al. Normal range values for thromboelastography in healthy adult volunteers. Braz. J. Med. Biol. 
Res. 2009 Dec. Vol. 42 (12). P. 1210-7.

16. Kitchen S, McCraw A, Echenagucia M. Diagnosis of hemophilia and other bleeding disorders. A laboratory manual. Second Edition. Montréal. World Federation of Hemophilia: 2010: 144

17. Kershaw G. Detection and measurement of factor inhibitors. Hemostasis and Thrombosis. 2017. 1646:295304.

DOI: 10.1007/978-1-4939-7196-1_23

18. Odegard, O.R. Lie M., Abildgaard U. Heparin cofactor activity measured with amidolytic method. Thromb. res. 1975 Apr. 6 (4): 287-94.

DOI: 10.1016/0049-3848(75)90078-X

19. Sehgal A., Barros S., Ivanciu L. Cooley B., Qin, Tim Racie et al. An RNAi therapeutic targeting antithrombin to rebalance the coagulation system and promote hemostasis in hemophilia Nat Med. 2015 May. 21(5): 492-7. DOI: 10.1038/nm.3847

21. Pasi K. John, Rangarajan Savita, Georgiev P. Mant T., Creagh M. D., Lissitchkovet T. et al. Targeting of Antithrombin in Hemophilia A or B with RNAi Therapy. N Engl J Med 2017 Jul; 377:819-28.

DOI: $10.1056 /$ NEJMoa1616569

Стаття надійила 16.08.2021

Контакти: valeriya-krasi@ukr.net
Res. 2009 Dec. Vol. 42 (12). P. 1210-7.

16. Kitchen S, McCraw A, Echenagucia M. Diagnosis of hemophilia and other bleeding disorders. A laboratory manual. Second Edition. Montréal. World Federation of Hemophilia: 2010: 144.

17. Kershaw G. Detection and measurement of factor inhibitors. Hemostasis and Thrombosis. 2017. 1646:295304.

DOI: 10.1007/978-1-4939-7196-1_23

18. Odegard, O.R. Lie M., Abildgaard U. Heparin cofactor activity measured with amidolytic method. Thromb. res. 1975 Apr. 6 (4): 287-94.

DOI: 10.1016/0049-3848(75)90078-X

19. Sehgal A., Barros S., Ivanciu L. Cooley B., Qin, Tim Racie et al. An RNAi therapeutic targeting antithrombin to rebalance the coagulation system and promote hemostasis in hemophilia Nat Med. 2015 May. 21(5): 492-7. DOI: 10.1038/nm.3847

21. Pasi K. John, Rangarajan Savita, Georgiev P. Mant T., Creagh M. D., Lissitchkovet $\mathrm{T}$. et al. Targeting of Antithrombin in Hemophilia A or B with RNAi Therapy. N Engl J Med 2017 Jul; 377:819-28.

DOI: $10.1056 /$ NEJMoa1616569 